\title{
URTICÁRIA DE CONTACTO INDUZIDA POR FÁRMACOS
}

\author{
Ana Gameiro', Miguel Gouveia', Leonor Ramos², Margarida Gonçalo³ \\ 'Interna de Dermatologia e Venereologia/Resident of Dermatology and Venereology, Serviço de Dermatologia e Venereologia do \\ Centro Hospitalar e Universitário de Coimbra, Portugal \\ ${ }^{2}$ Assistente Hospitalar de Dermatovenereologia/Consultant of Dermatology and Venereology, Serviço de Dermatologia, Centro \\ Hospitalar e Universitário de Coimbra, Coimbra, Portugal \\ ${ }^{3}$ Assistente Graduada Sénior, Chefe de Serviço, Assistente Convidada da Faculdade de Medicina da Universidade de Coimbra/ \\ Consultant Chief, Invited Professor of the Medical School of Coimbra University, Portugal
}

RESUMO - A dermatite de contacto inclui qualquer reação inflamatória da pele, secundária a contato direto ou indireto entre esta e agentes agressores. A expressão clínica mais comum é o eczema, ou outros padrões resultantes de reações retardadas, mas reações imediatas como a urticária de contacto podem também ocorrer. $\bigcirc$ espectro de manifestações clínicas por urticária de contacto é amplo. Na sua forma mais limitada, manifesta-se por urticária localizada à área de contacto entre o alergénio e a pele ou mucosa, e nos casos de apresentações mais exuberantes, podem surgir lesões urticariformes generalizadas, angioedema, ou mesmo anafilaxia. Em teoria, todos os fármacos tópicos podem ser responsáveis por urticária de contacto, e vários fármacos foram já descritos como indutores. As moléculas implicadas podem ser os princípios ativos ou os excipientes, por via de mecanismos imunológicos ou não. Os autores apresentam uma revisão dos diferentes fármacos descritos na urticária de contacto, dando enfâse à urticária de contacto das mucosas e em contexto profissional.

PALAVRAS-CHAVE - Anafilaxia/induzida quimicamente; Dermatite Alérgica de Contacto; Dermatite de Contacto; Hipersensibilidade a Medicamentos; Urticária/induzida quimicamente.

\section{CONTACT URTICARIA INDUCED BY DRUGS}

ABSTRACT - Contact dermatitis includes any inflammatory skin reaction due to direct or indirect skin contact with noxious agents. The main clinical expression is eczema and other delayed reactions, but immediate reactions, namely contact urticaria, can also occur. Contact urticaria has a broad range of clinical manifestations. The limited form is restricted to the area of contact between the allergen and the skin or mucosa, but more severe presentations include generalized urticaria lesions, angioedema and even anaphylaxis. All topical drugs can theoretically precipitate contact urticaria. The culprit may be either the active compound or the excipients, and the mechanisms of the immediate reactions can be both immune-mediated (IgE-dependent) and non-immune-mediated. The authors present an overview of the different drugs reported to induce contact urticaria, emphasizing the specific contexts of mucosal exposure and contact urticaria induced by drugs in occupational settings.

KEY-WORDS - Anaphylaxis/chemically induced; Dermatitis, Contact; Dermatitis, Allergic Contact; Drug Hypersensitivity; Urticaria/ chemically induced.

Conflitos de interesse: Os autores declaram não possuir conflitos de interesse. No conflicts of interest.

Suporte financeiro: $\bigcirc$ presente trabalho não foi suportado por nenhum subsídio ou bolsa. No sponsorship or scholarship granted. Recebido/Received - Julho/July 2015; Aceite/Accepted - Setembro/September 2015

Correspondência:

Dr. ${ }^{a}$ Ana Gameiro

Serviço de Dermatologia,

Centro Hospitalar e Universitário de Coimbra

Praceta Mota Pinto

3000-075 Coimbra, Portugal

Email: anaportelinhag@gmail.com 


\section{INTRODUCTION}

Contact dermatitis includes any inflammatory skin reaction due to direct or indirect skin contact with noxious agents. The main clinical expression is eczema, but other delayed reactions can occur (lichenoid, sarcoidal, and lymphomatous reactions, purpura and erythema multiform-like reactions); as well as immediate reactions, namely contact urticaria (CU) or protein-contact dermatitis. ${ }^{1,2}$

$\mathrm{CU}$ is not rare, particularly among atopic individuals; however, prevalence data are limited because the disease often remains undiagnosed due to the mildness of symptoms. ${ }^{3}$ Contact urticaria syndrome (CUS) is classified according to clinical severity: stage 1) urticaria localized to the area of contact with the offending drug; stage 2) generalized urticaria; stage 3) urticaria with associated systemic symptoms; and stage 4) anaphylaxis. ${ }^{4,5}$

A CU reaction occurs within minutes to 1 hour after cutaneous or mucosal exposure to a substance, and clears completely within hours, and no residual signs. Proteins (molecular weight 10,000 to several hundred thousand) and chemicals (molecular weights below 1,000) can both trigger CUS. ' Virtually any topical drug can induce an immediate reaction, but most cases have been described with topical antibiotics, NSAIDs and anesthetics, and more recently, with antiseptics such as chlorhexidine (Table 1). Published reports of $\mathrm{CU}$ induced by other drugs represent relatively exceptional cases.

Drugs intended for systemic use (oral or i.v.) can also cause immediate cutaneous contact symptoms upon direct contact or airborne exposure. ${ }^{6-9}$ Immediate symptoms have been described with oral drugs, generally initiated during their transient passage in the mouth before swallowing, inducing local symptoms with edema of the lips, oral and oropharyngeal mucosae; and such cases can progress to systemic urticaria.

When exposure occurs through mucosa or through skin wounds, CU onset is usually more rapid than via normal skin, probably due to an easier access of the offending drug to dermal mast cells. Moreover, mucosa exposure is more frequently associated with systemic symptoms, including anaphylaxis, which can be life-threatening. ${ }^{10,11}$

\section{PATHOGENESIS}

Drugs intended for skin application are usually small reactive compounds that can easily penetrate the epidermis, and eventually reach the dermis, where they can activate the mechanisms responsible for immediate symptoms. Drugs can induce both immune-mediated and non-immune-mediated CUS, the latter being more frequent. ${ }^{12}$

In case of non-immunologic mechanisms, drugs directly interfere with cutaneous mast cells and induce non-specific degranulation, or may interfere with other neurologic and vascular mediators (prostaglandins/leukotrienes, PAF, substance $\mathrm{P}$ or other neuropeptides), resulting in increased vascular permeability, vasodilation, dermal edema and pruritus. The mechanisms of non-immune-mediated, drug-induced immediate contact reactions have not been precisely studied for most drugs, but causal mechanisms have been identified in

Table 1 - Main drugs causing contact urticaria syndrome.

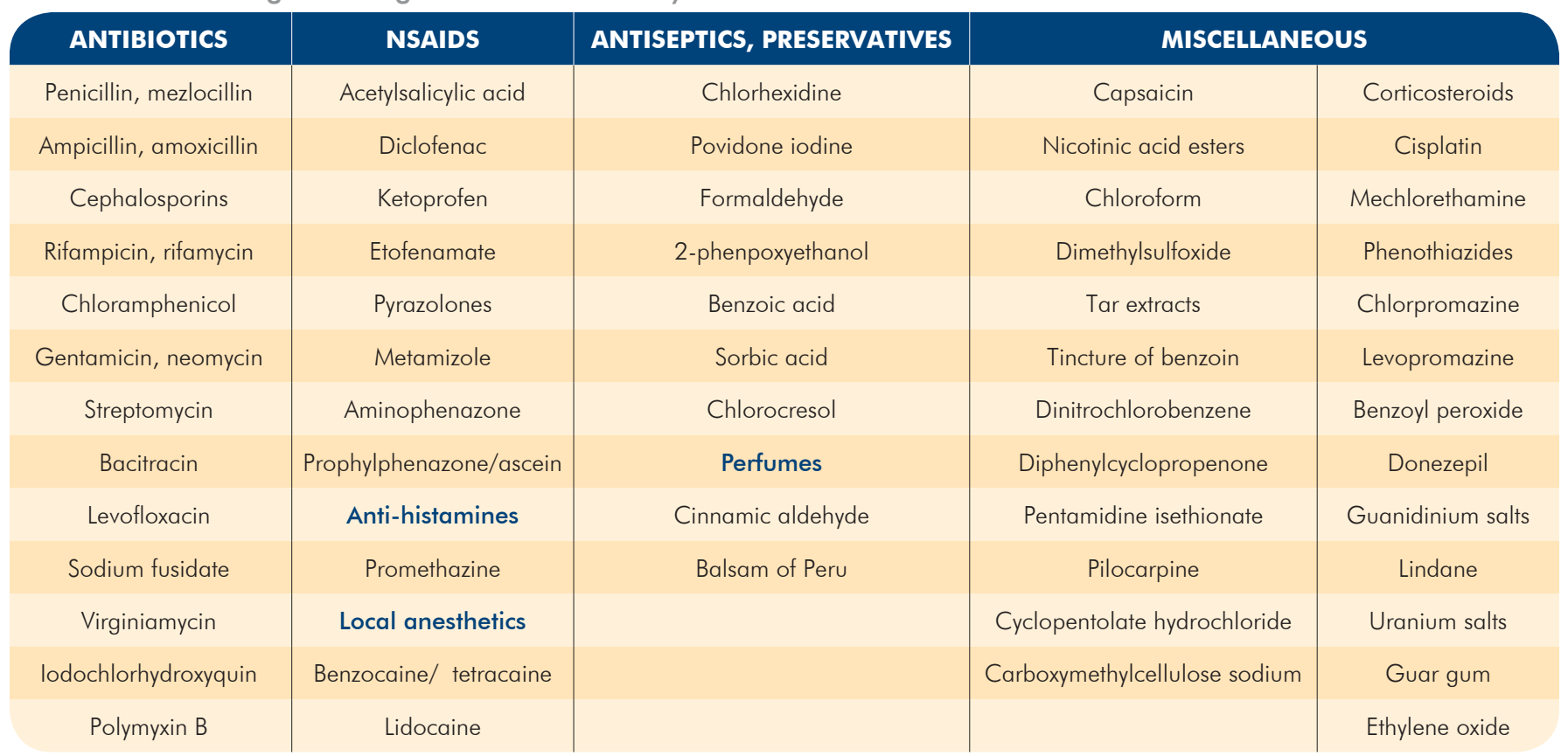


Table 2 - Contact urticaria mechanisms.

\begin{tabular}{|c|c|c|}
\hline Non-IgE dependent mechanism & $\begin{array}{c}\text { Proposed and demonstrated* } \\
\text { mechanisms }\end{array}$ & $\begin{array}{c}\text { Drug-specific IgE dependent mechanism } \\
\text { (Drug-specific IgE identified) }\end{array}$ \\
$\begin{array}{c}\text { Etofenamate, diclofenac, ketoprofen, } \\
\text { acetylsalicylic acid and other topical NSAIDs }\end{array}$ & $\begin{array}{c}\text { Imbalance between prostaglandins and } \\
\text { leukotrienes } \\
\text { Benzoic acid and sorbic acid }\end{array}$ & $\begin{array}{c}\text { Prostaglandin D2 release* } \\
\text { Capsaicin } \\
\text { Rifamycin }\end{array}$ \\
Cannabis & Release of substance P from nerve endings \\
Local anesthetics & - & Bacitracin \\
Perfumes & - & Chlorhexidine \\
\hline
\end{tabular}

particular cases, including the example of capsaicin, which releases substance $P$ from nerve endings ${ }^{4}$ (Table 2 ).

Drugs can also be specifically recognized by lgE on mast cells, basophils, and eventually by Langerhans cells, and other skin dendritic cells. In these cases, drugs likely act as haptens and combine with proteins (human serum albumin or other serum or skin proteins) prior to $\lg E$ recognition (Table 2). ${ }^{13} \lg \mathrm{E}$ recognition on mast cells and basophils can trigger a sequence of signaling events that result in cell degranulation, and release of histamine, cytokines, and other pre-formed mediators, or else activate phospholipase A, to release arachidonic acid for pro-inflammatory pathway. ${ }^{4}$

lgE-dependent CU that is induced by drugs or other agents, is usually more severe than $\mathrm{CU}$ induced by non-immunologic reactions, often extending beyond the application area, and being associated with facial angioedema, oropharyngeal edema or conjunctivitis; and with systemic symptoms such as cough, bronchospasm, dyspnea, abdominal cramps and, in some cases, anaphylaxis with bradycardia and hypotension. ${ }^{4}$

It is important to underline that both immediate and delayed hypersensitivity mechanisms may be concomitantly involved for a single agent, as in chlorocresol, an excipient of corticosteroid creams, or as in occupational airborne disinfectants. ${ }^{6}$

\section{CU FROM TOPICAL DRUGS APPLIED ON THE SKIN}

Many topical drugs used either on normal or damaged skin cause CUS. Both the active ingredient and a component of the vehicle can be responsible, and most represent a non-immunological reaction induced by perfumes or preservatives. $5,14,15$

Some of these immediate reactions manifest only as transient erythema and tingling, or as pruritus without wheals, usually resolving in less than 30-60 minutes. Therefore, they are not usually the subject of publication or more detailed study.

\subsection{Topical antibiotics}

$\mathrm{CU}$ in response to topical antibiotics is not frequent, but although only a few cases have been described they can be severe. Most published cases of CU or more severe immediate reactions from topical antibiotics are rather old, similarly to those induced by bacitracin and polymyxin $B,{ }^{16}$ rifamycin, 8,17 chloramphenicol, gentamycin, streptomycin, neomycin ${ }^{18}$ and viginiamycin. ${ }^{4}$ Nevertheless, a recent case reported CUS with severe systemic symptoms in a 16 year-old boy, following the use of sodium fusidate applied to skin with abrasions. ${ }^{9}$

Topical antibiotics are often used on skin with barrier defects, or even on open wounds or ulcers. This may favor sensitization and/or the effector reaction, due to easier access of the drug to the dermis. Also, in infected or wounded skin, previous activation of the innate immune system by pathogens and their pathogen-associated molecular patterns (PAMP), by inflammatory molecules and by danger-associated molecular patterns (DAMPs), may additionally facilitate a specific immune response that exacerbates the urticarial reaction.

\subsection{Topical antihistamines and NSAIDs}

Immediate reactions have been described with topical antihistamines such as promethazine; and with topical NSAIDs such as acetylsalicylic, metamizol and other pyrazolone compounds, ${ }^{4,19,20}$ diclofenac, ${ }^{21}$ etofenamate ${ }^{22}$ and ketoprofen ${ }^{23}$; and other drugs such as aescin. ${ }^{24}$ However, those reports were mostly isolated cases, dating back to the 1990s.

\subsection{Topical anesthetics}

Local anesthetics applied on normal skin have been described as a cause of CU, namely benzocaine cream ${ }^{18}$ and especially creams containing lidocaine. Contrasting with its low capacity to induce delayed hypersensitivity reactions, ${ }^{25}$ lidocaine has caused $\mathrm{CU}$ in a hemorrhoidal $\mathrm{cream}^{7}$; in a combination of lidocaine and tetracaine $(7 \% \text { each })^{26}$; and in $\mathrm{EMLA}^{\circledR}$ 
cream, an eutectic mixture of lidocaine and prilocaine at $2.5 \%$ each. ${ }^{25}$

\subsection{Topical antiseptics}

Topical antiseptics such as povidone iodine ${ }^{27,28}$ and chlorhexidine ${ }^{29,30}$ are particularly involved in immediate reactions when applied to surgical or other open wounds, or to the mucosa.

\section{CONTACT URTICARIA FROM MUCOSAL EXPOSU- RE TO DRUGS}

Exposure through mucosa is often associated with more rapid onset of reaction and more severe symptoms, even upon very discrete exposure to the offending drug.

The conjunctiva has been the exposure site for localized or generalized urticaria or even anaphylaxis induced by eye drops, i.e. levofloxacin and mydriatic cyclopentolate hydrochloride eye drops..$^{31-33}$

The oral mucosa has been the exposure site for cases of $\mathrm{CU}$ induced by anesthetic gels containing lidocaine and guar gum in the excipient ${ }^{34}$; by chlorhexidine used in dental endodontic procedures, ${ }^{30}$ mouth washes ${ }^{10}$ and toohtpastes ${ }^{35}$; and also by formaldehyde used in dental procedures. ${ }^{36}$

Exposure of the vaginal mucosa to chlorhexidine ${ }^{29}$ or povidone iodine ${ }^{37}$ during gynecological procedures has been associated with generalized urticaria. Chlorhexidine has also been involved in $\mathrm{CU}$ after the insertion of central catheters or intra-urethral catheters soaked in this antiseptic, namely Instillage ${ }^{\circledR}$, which contains both chlorhexidine and lidocaine. ${ }^{38}$

Perioperative urticaria or anaphylaxis can also be a presentation of $\mathrm{CU}$, mainly by contact with latex or ethylene oxide used for the disinfection of material (masks), ${ }^{38}$ but also by the antiseptics chlorhexidine and povidone iodine ${ }^{21}$ or by the antibiotics rifamycin and bacitracin used for surgical wound disinfection. ${ }^{29}$

\section{CONTACT URTICARIA FROM DRUGS IN OCCUPA- TIONAL SETTINGS}

Occupational CU from drugs occurs mainly in nurses who prepare injectable drugs, and in nurses and other caregivers who are required to crush and handle tablets. ${ }^{39} \mathrm{CU}$ in the pharmaceutical industry is rare, as most drugs are produced in closed circuits involving little or no contact with the worker. ${ }^{5}$ The main allergen associated with $\mathrm{CU}$ among the health care population is latex, although the incidence has declined significantly in recent years by improving latex production and through the use of powder-free gloves. ${ }^{3}$

Frequent chronic hand eczema in nurses, due to irritation, delayed allergy, or atopic dermatitis, consequently with a disturbed skin barrier, may contribute to enhanced drug penetration through the epidermis and thereby easier access of potential allergens to dermal mast cells. Continuous hand exposure to drugs recognized by lgE can also induce immediate vesicular reactions; as in protein contact dermatitis, this can contribute significantly to aggravation and persistence of chronic hand eczema in this occupational setting. ${ }^{40}$

Nurses with occupational CU mostly complain of transient hand edema or swelling in association with pruritus or paresthesia. Lesions on the face, neck and forearms can also occur, eventually with generalization of urticaria and systemic symptoms (cough, dyspnea, asthma, rhinorrhea or abdominal cramps), particularly upon airborne exposure to volatile substances or powders of the drug. ${ }^{41}$

The drugs primarily associated with occupational $\mathrm{CU}$ are the antibiotics, particularly penicillin, ampicillin, amoxicillin and the cephalosporins. ${ }^{38,42,43}$ Apart from antibiotics, other drug-induced cases of CU have been reported in health care workers, namely with chlorhexidine, donepezil, and cisplatin. ${ }^{34,44,45}$

\section{DIAGNOSIS OF IMMEDIATE SYMPTOMS INDU- CED BY DRUGS}

The diagnosis of $\mathrm{CU}$ induced by drugs is based mainly on clinical history, which requires very precise data on the timing of events (drug exposure and initiation of symptoms), and the localization of lesions (initial localization and progression).

When urticaria is preceded by exposure to multiple drugs (topical and systemic), it is extremely important to perform complementary tests in order to achieve a precise diagnosis, and to enable the culprit drug to be avoided in future. When the patient has been exposed to a single drug, complementary tests may be important to confirm the etiology, evaluate cross-reactivity to related chemicals, ${ }^{46}$ to identify a safe alternative drug and, eventually, to appreciate the participation of drug-specific $\lg \mathrm{E}$.

The development of urticaria or anaphylaxis preoperatively is often incorrectly attributed to systemic drugs, as they are the main cause of urticaria in these settings (neuromuscular blockers, antibiotics, anesthetics, opiates, analgesics such as metamizol or radiocontrast media). ${ }^{11,29}$ However, topical drugs can be the cause, as shown in a recent study where chlorhexidine represented $5 \%$ of all perioperative anaphylaxis cases. ${ }^{29}$

To prevent avoidable cases of severe reactions during skin testing, the study of such patients should begin with open epicutaneous tests in normal skin, and occlusive patch tests on the forearms with immediate readings (20-30 minutes). If negative, they should be followed by skin prick tests, and eventually, by intracutaneous tests (Fig. 1). These tests should be performed in settings where there is easy access to resuscitation measures, since generalization of urticaria from skin testing, or even anaphylaxis ${ }^{36,38}$ can occur, particularly in the study of severe $\mathrm{CU}$ or anaphylactic reactions. When organs other than skin are involved, it is important to begin testing with a diluted 


\section{Open application}

$\boldsymbol{\downarrow}$ (negative)

\section{Occlusive application (patch or chamber) (negative) \\ Prick test \\ $\Downarrow$ (negative)}

Intradermal test

Fig 1 - Contact urticaria diagnosis.

allergen. Nevertheless, there are few standardized drug preparations for skin testing, namely for epicutaneous patch testing, and even fewer for skin prick or intracutaneous testing.

Topical drugs and dressings can be tested as such in open epicutaneous tests, on the volar forearm; subsequently, a lancet puncture can be performed across the material applied to the skin. For prick testing with drugs, sterile dilutions from commercial preparations have to be performed, preferably from i.v. preparations. There is no consensus on the dilutions to be used, but in more severe reactions it is advisable to begin with higher dilutions and to increase the concentration progressively in case of negative tests $\left(10^{-3}, 10^{-2}, 10^{-1}\right.$, then pure), or to follow the concentrations recommended by the $\mathrm{ESCD}^{46}$ and ENDA/EAACl study groups ${ }^{47}$ for the assessment of adverse effects of systemic drugs.

Results have always to be compared with the positive control (histamine $10 \mathrm{mg} / \mathrm{ml}$ ) and negative control (saline). According to the guidelines for prick testing, only papular erythematous reactions with a diameter $>3 \mathrm{~mm}$ are considered positive. ${ }^{46}$

The sensitivity of in vivo testing is usually higher than in vitro tests, but it is important to be aware that some drugs (opioids, non-steroidal anti-inflammatory drugs - NSAIDs) cause non-specific mast cell degranulation and, consequently, false-positive reactions. Therefore, in positive results, particularly with unknown drugs, skin testing in at least 20 control patients is mandatory to confirm the specificity of the positive reaction.

Reagents for specific lgE (in vitro test) are commercialized only for a limited number of drugs and excipients potentially involved in CU, namely beta-lactam antibiotics, chlorhexidine, formaldehyde, ethylene oxide and gelatin, and for a few others that can cause urticaria upon systemic exposure. ${ }^{48,49}$ BAT (basophil activation tests) evaluation for degranulation of basophils upon in vitro exposure to the chemical, and the increase in basophil expression of CD63 or CD203c evaluated by flow cytometer, can be performed in selected laboratories, but these tests are less specific. ${ }^{50}$ Measuring serum tryptase during the acute episode, or within the first 2-4 hours after a stage 3 CUS or anaphylaxis, and comparison with basal values (>24h), is a useful complementary test to document mast cell/basophil degranulation, but does not confirm the etiology of the reaction. ${ }^{37}$ Controlled exposure to the suspected drug, or to safe alternative drugs may be advisable when all previous tests were negative.

\section{CONCLUSIONS}

Topical drugs, or occasionally systemic drugs, that come into contact with the skin or mucosa may induce $\mathrm{CU}$, which is often overlooked because some reactions are mild and ignored by patients. Moreover, as such effects are transient, they are seldom present at the time of consultation or at the time of testing, which makes diagnosis difficult. Complementary tests (skin tests with immediate readings and, eventually, in vitro tests) are mandatory in certain situations, as precise diagnosis of the culprit drug and identification of safe alternative drugs can be life-saving.

\section{REFERENCES}

1. Giménez-Arnau A, Maibach $\mathrm{H}$. Contact urticaria syndrome: Definition, history, etiology, and relevance. In: Gimenez-Arnau AM, Maibach HI, editors. Contact Urticaria Syndrome. Leiden: CRC Press; 2014. p.1-8.

2. Aalto-Korte Kand Suomela S. Contact Urticaria Syndrome: Epidemiology and Occupational Relevance. In: Gimenez-Arnau AM, Maibach HI, editors. Contact Urticaria Syndrome. Leiden: CRC press; 2014. p.9-14.

3. Giménez-Arnau A. Contact urticaria and the environment. Rev Environ Health. 2014; 29:207-15.

4. Gimenez-Arnau A, Maurer M, De La Cuadra J, Maibach $\mathrm{H}$. Immediate contact skin reactions, an update of contact urticaria, contact urticaria syndrome and protein contact dermatitis - "A Never Ending Story". Eur J Dermatol. 2010; 20:552-62.

5. Amaro C, Goossens A. Immunological occupational contact urticaria and contact dermatitis from proteins: a review. Contact Dermatitis. 2008; 58:67-75.

6. Gonçalo M, Gonçalo S, Moreno A. Immediate and delayed hypersensitivity to chlorocresol. Contact Dermatitis. 1987; 17:46-7.

7. Jovanovic M, Karadaglic D, Brkic S. Contact urticaria and allergic contact dermatitis to lidocaine in a patient sensitive to benzocaine and propolis. Contact Dermatitis. 2006; 54:124-6.

8. Grob J, Pommier G, Robaglia A, Collet-Villette A, Boneradi JJ. Contact urticaria from rifamycin. Contact 
Dermatitis. 1987; 16:284-5.

9. Park M-R, Kim D-S, Kim J, Ahn K. Anaphylaxis to topically applied sodium fusidate. Allergy Asthma Immunol Res. 2013; 5:110-2.

10. Doutre M-S. Occupational contact urticaria and protein contact dermatitis. Eur J Dermatol. 2005; 15:419-24.

11. Williams J, Lee A, Metheson M, Frowen K, Noonan A, Nixon R. Occupational contact urticaria: Australian data. Br J Dermatol. 2008; 159:125-31.

12. Martin S. Contact dermatitis: from pathomechanisms to immunotoxicology. Exp Dermatol. 2012; 21:382-9.

13. Filipe P. Urticária crónica: novas perspectivas terapêuticas. Rev Soc Port Dermatol Venereol. 2015; 73:55-60.

14. Co-Minh H, Demoly P, Guillot B, Raison-Peyron N. Anaphylactic shock after oral intake and contact urticaria to polyethylene glycols. Allergy. 2007; 62:92-3.

15. Brinca A, Cabral R, Gonçalo M. Contact allergy to local anaesthetics-value of patch testing with a caine mix in the baseline series. Contact Dermatitis. 2013; 68:156-62.

16. Knowles SR, Shear NH. Anaphylaxis from bacitracin and polymyxin B (Polysporin) ointment. Int J Dermatol. 1995; 34:572-3.

17. Mancuso G, Masara N. Contact urticaria and severe anaphylaxis from rifamycin SV. Contact Dermatitis. 1992; 27:124-5.

18. Kim E, Maibach H. Contact urticaria. In: Greaves M, Kaplan $A$, editors. Urticaria and angioedema. New York: Marcel Dekker, Inc.; 2004. p.149-69.

19. Maucher O, Fuchs A. Contact urticaria caused by skin test in pyrazolone allergy. Hautartz. 1983; 34:383-6.

20. Lombardi P, Giorgini S, Achille A. Contact urticaria from aminophenazone. Contact Dermatitis. 1983; 9:428-9.

21. Jonker M, Bruynzeel D. Anaphylactic reaction by patch testing with diclofenac. Contact Dermatitis. 2003; 49:114-5.

22. Piñol J, Carapeto F. Contact urticaria to etofenamate. Contact Dermatitis. 1984; 11:133.

23. Suzuki T, Kawada A, Hashimoto $Y$, Isogai R, Aragane $Y$, Tezuka T. Contact urticaria due to ketoprofen. Contact Dermatitis. 2003; 48:284-5.

24. Escribano M, Muñoz-Bellido F, Velazquez E, Delgado J, Serrano P, Guardia J, et al. Contact urticaria due to aescin. Contact Dermatitis. 1997; 37:233.

25. Waton J, Boulanger A, Trechot PH, Schmutz JL, Barbaud A. Contact urticaria from Emla cream. Contact Dermatitis. $2004 ; 51: 284-7$.

26. Channual J, Wu J, Zachary C. Localized contact urticaria caused by lidocaine/tetracaine peel. Arch Dermatol. $2009 ; 145$.

27. Caballero M, Lukawaska J, Dugué P. A hidden case of perioperative anaphylaxis. J Invest Clin Immunol. 2010;
20:353-4.

28. Adachi A, Fukunaga A, Hayashi K, Horikawa T. Anaphylaxis to polyvinylpirrolidone after vaginal application of povido-iodine. Contact Dermatitis. 2003; 48:133-6.

29. Antunes J, Kochuyt A-M, Ceuppens JL. Perioperative allergic reactions: Experience in a Flemish referral centre. Allergol et Immunopathol. 2014; 42:348-54.

30. Keni NN, Aras $M$, Chitre V. Chlorhexidine allergy due to topical application. Indian J Dent Res. 2012; 23:674-6.

31. Aranda A, Mayorga C, Ariza A, Doña I, Rosado A, Blanca-Lopez $\mathrm{N}$, et al. In vitro evaluation of IgE-mediated hypersensitivity reactions to quinolones. Allergy. 2011; 66:247-54.

32. Saito M, Nakada T. Contact urticaria syndrome from eye drops: levofloxacin hydrate ophthalmic solution. J Dermatol. 2013; 40:130-1.

33. Muñoz-Bellido FJ, Beltrán A, Bellido J. Contact urticaria due to cyclopentolate hydrochloride. Allergy Asthma Immunol Res. 2000; 55:198-9.

34. Roesch A, Haegele T, Vogt T, Babilas P, Landthaler $M$, Szeimies RM. Severe contact urticaria to guar gum included as gelling agent in a local anaesthetic. Contact Dermatitis. 2005; 52:307-8.

35. Wittczak T, Dudek W, Walusiak-Skorupa J, Swierczynska-Machura D, Pałczynski C. Chlorhexidine-still an underestimated allergic hazard for health care professionals. Occup Med.2013; 63:301-5.

36. Moder B, Kranke B. Anaphylactic reaction to formaldehyde. Allergy. 2001; 56:263-4.

37. Michavila Gomez A, Belver Gonzalez M, Alvarez N, Giner Muñoz M, Hernando Sastre V, Porto Arceo J, et al. Perioperative anaphylactic reactions: Review and procedure protocol in paediatrics. Allergol Immunopathol. 2015; 43:203-14.

38. Choi IS, Han E-R, Lim S-W, Lim S-R, Kim J-N, Park S-Y, et al. Beta-lactam antibiotic sensitization and its relationship to allergic diseases in tertiary hospital nurses. Allergy, Asthma Immunol Res. 2010; 2:114-22.

39. Fellinger C, Wantke F, Hemmer W, Sesztak-greinecker $\mathrm{G}$, Wöhrl S. The rare case of a probably true IgE-mediated allergy to local anaesthetics. Case Rep Med. 2013; 2013:201586.

40. Couto M, Gaspar A, Piedade S, Arêde C, Menezes M, Sousa MJ, et al. IgE-mediated metamizol allergy and the usefulness of the cellular allergen stimulation test. Eur Ann Allergy Clin Immunol. 2012; 44:113-6.

41. Mihyhara H, Koga T, Imayama S, Hori Y. Ocupational contact urticaria syndrome from cefotiam hydrochloride. Contact Dermatitis. 1993; 29:210-1.

42. Condé-Salazar L, Guimaraens $D$, González M a, Mancebo E. Occupational allergic contact urticaria from 
amoxicillin. Contact Dermatitis. 2001; 45:109.

43. Galvez Lozano JM, Alcantara M, De San Pedro BS, Quiralte J, Caba I. Occupational contact urticaria caused by donepezil. Contact Dermatitis. 2009; 61:176.

44. Schena D, Barba A, Costa G. Occupational contact urticaria due to cisplatin. Contact Dermatitis. 1996; 34:220.

45. Nunez Orjales R, Carballas Vázquez C, Carballada González F, Boquete Pars M. 2-Phenoxyethanol-induced contact urtcaria and anaphylaxis. J Investig Allergol Clin Immunol. 2010; 20:354-5.

46. Barbaud A, Gonçalo M, Bircher A, Bruynzeel D. Guidelines for performing skin tests with drugs in the investigation of cutaneous adverse drug reactions. Contact Dermatitis. 2001 ; 45:321-8.

\section{GPDEC}

47. Brockow K, Garvey LH, Aberer W, Atanaskovic-Markovic $M$, Barbaud A, Bilo $M B$, et al. Skin test concentrations for systemically administered drugs-an ENDA/EAACI Drug Allergy Interest Group position paper. Allergy. 2013; 68:702-12.

48. Kim JE, Kim SH, Choi GS, Ye YM, Park HS. Detection of specific IgE antibodies to cefotiam-HSA conjugate by ELISA in a nurse with occupational anaphylaxis. Allergy. 2010; 65:791-2.

49. Kim JE, Kim SH, Jin HJ, Hwang EK, Kim JH, Ye YM, et al. IgE sensitization to cephalosporins in health care workers. Allergy Asthma Immunol Res. 2012; 4:85-91.

50. Sanz M, Gamboa P, Weck A. In vitro tests: Basophil activation tests. In: Pichler W, editor. Drug Hypersensitivity. Basel: Karger; 2007. p. 391-402. 